\title{
Development of a qPCR to diagnose the genus Eimeria in bovines
}

\section{Desenvolvimento de uma qPCR para o diagnóstico do Gênero Eimeria em bovinos}

\author{
Sérgio Tosi Cardim ${ }^{1 *}$; Stefani Lino Cardim²; Mércia de Seixas ${ }^{1}$; Alessandra \\ Taroda $^{3}$; Priscilla Gomes Carneiro ${ }^{3}$; Dauton Luiz Zulpo ${ }^{4}$; Luiz Daniel de Barros ${ }^{5}$; \\ Guilherme Luis Bortolloti'; João Luis Garcia ${ }^{5}$
}

\author{
Highlights: \\ Fastest diagnosis of genus Eimeria in cattle. \\ High sensitivity of qPCR. \\ Faster prognosis with decreased animal injuries.
}

\begin{abstract}
Bovine coccidiosis is caused by protozoa in the genus Eimeria. These protozoa mainly affect young animals, causing a decrease in production and consequent economic losses. The routine diagnosis is made through morphological observation of the oocysts, which has several limitations. The objective of the present study was to develop a real-time PCR (qPCR) technique for the diagnosis of Eimeria spp. in cattle. For this purpose, the $18 \mathrm{~S}$ rRNA region of the DNA of these parasites was selected because it is a region with low variability among the species. The qPCR technique was developed using SYBR Green, resulting in a PCR with high sensitivity, and the ability to amplify samples containing only one oocyst of an Eimeria spp. in bovines. The feasibility of using qPCR in the diagnosis of the genus Eimeria was demonstrated in this study. This technique is less laborious and requires less skill and diagnostic training compared to the technique conventionally used for this diagnosis (micromorphometry).
\end{abstract}

Key words: $18 \mathrm{~S}$ rRNA. Cattle. Coccidiosis. Eimeria. qPCR.

\section{Resumo}

A coccidiose em bovinos é causada por protozoários do gênero Eimeria. Estes protozoários acometem principalmente animais jovens, causando diminuição de produção e consequente perdas econômicas. O diagnóstico de rotina é realizado através de observação morfológica dos oocistos, que possui várias

1 Profs. Drs., Universidade Norte do Paraná, UNOPAR, Arapongas, PR, Brasil. E-mail: stcardim@hotmail.com; mercia_seixas@ yahoo.com.br

2 Discente do Curso de Doutorado do Programa de Pós-Graduação em Fisiopatologia Clínica e Laboratorial, Universidade Estadual de Londrina, UEL, Londrina, PR, Brasil. E-mail: stefanilino@hotmail.com

3 Discentes do Curso de Doutorado do Programa de Pós-Graduação em Ciência Animal, UEL, Londrina, PR, Brasil. E-mail: aletaroda@gmail.com; pirt1987@hotmail.com

4 Prof. Dr., Faculdade de Medicina Veterinária, Pontifícia Universidade Católica do Paraná, PUC, Toledo, PR, Brasil. E-mail: dau_zulpo@yahoo.com.br

5 Profs. Drs., Departamento de Medicina Veterinária Preventiva, Centro de Ciências Agrárias UEL, Londrina, PR, Brasil. E-mail: ldbarros@uel.br; joaoluisgarcia10@gmail.com

6 Discente do Curso de Mestrado do Programa de Pós-Graduação em Saúde e Produção Animal, UNOPAR, Arapongas, PR, Brasil. E-mail: guilherme.bortolloti@hotmail.com

* Author for correspondence 
limitações. O objetivo do presente trabalho foi desenvolver uma técnica de qPCR para diagnóstico de Eimeria spp. em bovinos. Para isto foi selecionada a região 18S rRNA do DNA destes parasitas, pois a mesma é uma região com pouca variabilidade entre as espécies. A qPCR foi desenvolvida com a utilização de SYBR Green, tendo como resultado uma PCR com uma alta sensibilidade, capaz de amplificar amostras contendo apenas um oocisto de Eimeria spp de bovinos. Demonstra-se nesse estudo a viabilidade na utilização da qPCR no diagnóstico do gênero Eimeria, sendo esta técnica menos laboriosa e com menos necessidade de treinamento para diagnóstico quando comparada com a técnica convencionalmente utilizada em rotina (micromorfometria).

Palavras-chave: qPCR. Eimeria. Coccidiose. 18S rRNA. Bovinos.

\section{Introduction}

Bovine coccidiosis is a disease caused by a protozoan from the class Coccidia, family Eimeriidae, and genus Eimeria (Bruhn et al., 2011). This disease is one of the most common among bovines worldwide, and primarily occurs in animals less than 1 year of age (Daugschies, Imarom, Ganter, \& Bollwahn, 2004; Bruhn et al., 2011).

Over 20 species of Eimeria have been described in cattle, with Eimeria bovis and Eimeria zuernii considered pathogenic because they have been associated with clinical coccidiosis cases in young animals (Bangoura, Mundt, Schmäschke, Westphal, \& Daugschies, 2011; Jonsson, Piper, Gray, Deniz, \& Constantinoiu, 2011; Florião, Lopes, Berto, \& Lopes, 2016). Eimeria alabamensis has also been associated with mild diarrhea in animals raised on pasture (Svensson, Hooshmand-Rad, Pehrson, Törnquist, \& Uggla, 1993, Svensson, Uggla, \& Pehrson, 1994; Marshall, Catchpole, Green, \& Webster, 1998; Svensson, 2000). This disease causes substantial economic losses associated with decreased animal production, increasing susceptibility to other illnesses, and consequently, expenses associated with medicines (Abebe, Wossene, \& Kumsa, 2008). It has had an estimated 400 million dollar impact on the American market with over 3.8 million dollars spent on treatment in Canada (Matjila \& Penzhorn, 2002; Rehman et al., 2011). The economic impact of this illness in Brazil is unknown.

The occurrence of this parasite varies from 10 to $100 \%$ (Lentze, Hofer, Gottstein, Gaillard, \&
Busato, 1999; Stewart, Smith, \& Ellis-Iversen, 2008; Almeida, Magalhães, Muniz, \& Munhoz, 2011; Bruhn et al., 2011, 2012; Koutny, Joachim, Tichy, \& Baumgartner, 2012). According to studies evaluating different countries, the prevalence in Brazil varies from $33.33 \%$ to $48.2 \%$ (Rebouças et al., 1994; Almeida et al., 2011; Bruhn et al., 2011, 2012; Hillesheim \& Freitas, 2016).

A few studies have been conducted to develop PCR assays to diagnose Eimeria spp. Kawahara et al. (2010) developed a PCR technique using primers designed to begin annealing at the $18 \mathrm{~S}$ rRNA region and finish at the $5.8 \mathrm{~S}$ region, running through the ITS-1 region, to diagnose the genus and to determine the applicability of the primer design to diagnose species of this parasite in bovines. In another study, a primer was obtained for the genus Eimeria based on the 18S rRNA site, targeting the construction of a phylogenetic tree consisting of the main species in cattle (Kokozawa, Ichikawa-Seki, \& Itagaki, 2013).

Concerning technological advancements, new assays, such as real-time PCR (qPCR) are now available and capable of developing a more sensitive and specific diagnosis compared to that of conventional PCR. Hence, the goal of the present study was to develop and standardize a qPCR technique to diagnose Eimeria spp. in bovines.

\section{Material and Methods}

\section{Samples}

Fecal samples from bovines were sent to the Veterinary Parasitology Laboratory of the State 
University of Londrina. Ten positive samples for Eimeria spp. from naturally infected animals were selected and stored in $2.0 \mathrm{~mL}$ microtubes at $-20^{\circ} \mathrm{C}$.

To evaluate the sensitivity of the test, a single oocyst from each species of Eimeria spp. (E. bovis, E. alabamensis, and E. zuernii) were collected for DNA extraction. The oocysts were collected using a Pasteur glass pipette under an optical microscope, and each oocyst was placed in a $2.0-\mathrm{mL}$ microtube and diluted with $300 \mu \mathrm{L}$ of sterile ultrapure water. The samples were stored at $-20^{\circ} \mathrm{C}$ for further extraction.

For the same assay, two additional samples were used, including a positive fecal sample for Giardia spp. and a positive sample for Cryptosporidium spp. These samples were used to evaluate the specificity of the primers developed in this study.

\section{DNA extraction}

For DNA extraction, $25 \mathrm{mg}$ of stool was diluted in $300 \mu \mathrm{L}$ of sterile ultrapure water, followed by three cycles of freezing at $-80^{\circ} \mathrm{C}$ for $10 \mathrm{~min}$ and thawing at $55^{\circ} \mathrm{C}$ for $10 \mathrm{~min}$. Next, $15 \mu \mathrm{L}$ of proteinase $\mathrm{K}$ $\left(1 \mathrm{mg} \mathrm{mL}^{-1}\right)$ and $30 \mu \mathrm{L}$ of $0.1 \%$ SDS were added and the solution was incubated overnight at $55^{\circ} \mathrm{C}$. Subsequently, $300 \mu \mathrm{L}$ of UltraPure ${ }^{\mathrm{TM}}$ Phenol (Invitrogen, USA) was added and centrifuged at $13,000 \times \mathrm{g}$ for $5 \mathrm{~min}$. The resulting liquid was transferred to another microtube and $300 \mu \mathrm{L}$ of a mixture of UltraPure ${ }^{\mathrm{TM}}$ Phenol: chloroform: isoamyl alcohol (25:24:1, v/v) (Invitrogen, USA) was added and centrifuged at $13,000 \times g$ for $5 \mathrm{~min}$. The DNA was precipitated with sodium acetate and ethanol according to the method described by Sambrook, Fritshc and Maniatis (1989). The microtubes with extracted DNA were stored at $-20^{\circ} \mathrm{C}$ until use.

The DNA from the single oocyst samples for each species were individually obtained following the same freeze and thaw procedures and the DNA extraction process described above.

\section{Primers design}

The primers were designed from the $18 \mathrm{~S}$ rRNA gene sequences of Eimeria spp. and deposited at GeneBank with the following accession numbers: KU641163.1; KU641162.1; KU641161.1; KU641160.1; $\quad$ KU641159.1; $\quad$ KU641158.1; KU641157.1; KU641156.1; KU641155.1; KU641154.1; KU641153.1; $\quad$ KU641153.1; KU351737.1; $\quad$ KU351736.1; $\quad$ KU351735.1; KU351734.1; KU351733.1; KU351732.1; KU351731.1; $\quad$ KU351730.1; $\quad$ KU351729.1; KU351728.1; KU351727.1; KU351726.1; KU351725.1; KU351719.1; $\quad$ KU351718.1; KU351717.1; $\quad$ AY876932.1; $\quad$ AY876931.1; AY876930.1; $\quad$ AY876929.1; $\quad$ AY876928.1; AY876927.1; and AY876926.1.

After the selection of the sequences, the primers were aligned using the BioEdit program. Following the alignment, a specific site was selected and used for primer design, which was performed with Primer Express 3.0.1 (Thermo Fisher Scientific, USA). The primers obtained were named Eim18SF (AGC TTT CGA CGG TAG GGT ATT G) and Eim18SR (CGA ACC CTA ATT CCC CGT TAC) having an amplicon of $62 \mathrm{bp}$.

\section{PCR amplification}

DNA amplification was performed with $10 \mu \mathrm{L}$ of the total reaction and contained $5 \mu \mathrm{L}$ of $\mathrm{SYBR}^{\circledR}$ Select Master Mix (Thermo Fisher Scientific, USA), $200 \mathrm{nM}$ of each primer (Eim18SF and Eim18R), 0.4 $\mu \mathrm{L}$ of BSA $\left(1 \mathrm{mg} \mathrm{mL}^{-1}\right)$, and $1 \mu \mathrm{L}$ of DNA. The reaction cycle was run with an initial denaturation at $95^{\circ} \mathrm{C}$ for $10 \mathrm{~min}$, followed by 40 cycles of $94^{\circ} \mathrm{C}$ for $15 \mathrm{~s}, 57^{\circ} \mathrm{C}$ for $30 \mathrm{~s}$, and $72^{\circ} \mathrm{C}$ for $30 \mathrm{~s}$ (the step when the reading was conducted). To obtain the melting curve, the reaction was continued at $94^{\circ} \mathrm{C}$ for $15 \mathrm{~s}$ and $57^{\circ} \mathrm{C}$ for $1 \mathrm{~min}$, and then the temperature was increased to $95^{\circ} \mathrm{C}$, being read every $0.3^{\circ} \mathrm{C}$. 


\section{Results and Discussion}

In the present study, the $18 \mathrm{~S}$ rRNA site of the DNA from several species of Eimeria spp. of bovines was used to design primers, because this is a highly conserved region among species (Ogedengbe, Hanner, \& Barta, 2011).

The results showed it was possible to find samples containing a single oocyst of Eimeria spp., as seen in Figure 1. This demonstrated that the assay showed high sensitivity and could be a useful tool for routine diagnosis. These sensitive results resemble those obtained by Kokozawa et al. (2013) who used a conventional PCR, which was also based on the $18 \mathrm{~S}$ rRNA site, to amplify a single oocyst of this protozoan, with the goal of subsequent sequencing and evaluation of genetic variability among oocysts from the same species.

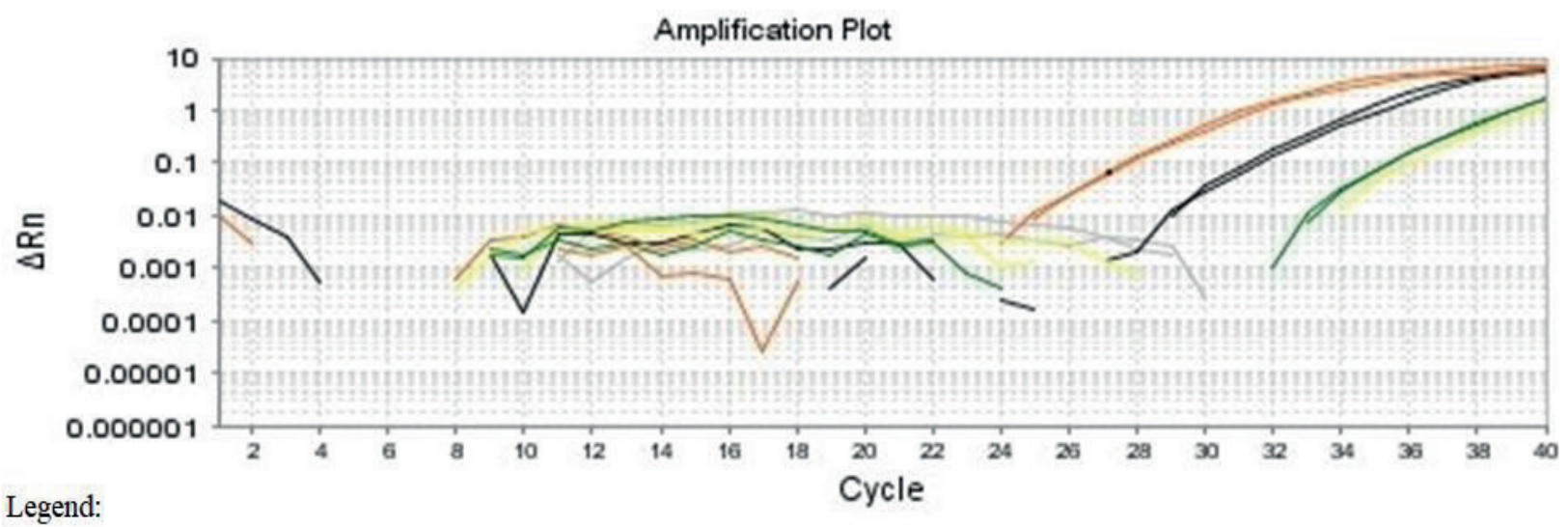

Eimeria bovis + Eimeria zuernii (400 oopg)

Eimeria alabamensis + Eimeria bovis + Eimeria zuernii (2000 oopg)

Eimeria zuernii (1 oocyst)

Eimeria alabamensis (1 oocyst)

Negative control

Figure 1. qPCR amplification curve for Eimeria spp. based on the $18 \mathrm{~S}$ rRNA region.

PCR using Cryptosporidium spp. and Giardia spp. samples showed negative results for both genera, which demonstrated the specificity of the primers used for this Eimeria study.

Once the SYBR Green was used in this qPCR, the melting curve was generated to look for primer dimers or inespecific reactions. A small amount of primer dimers was noted in addition to a significant decrease in primer concentration (Figure 2).
A few studies have used the melting curve for parasitic species differentiation by examining the differences between the dissociation temperatures (Nicolas, Milon, \& Prina, 2002; Khademvatan, Neisi, Maraghi, \& Saki, 2011). This could not be performed in the present study because of similar dissociation temperatures. 


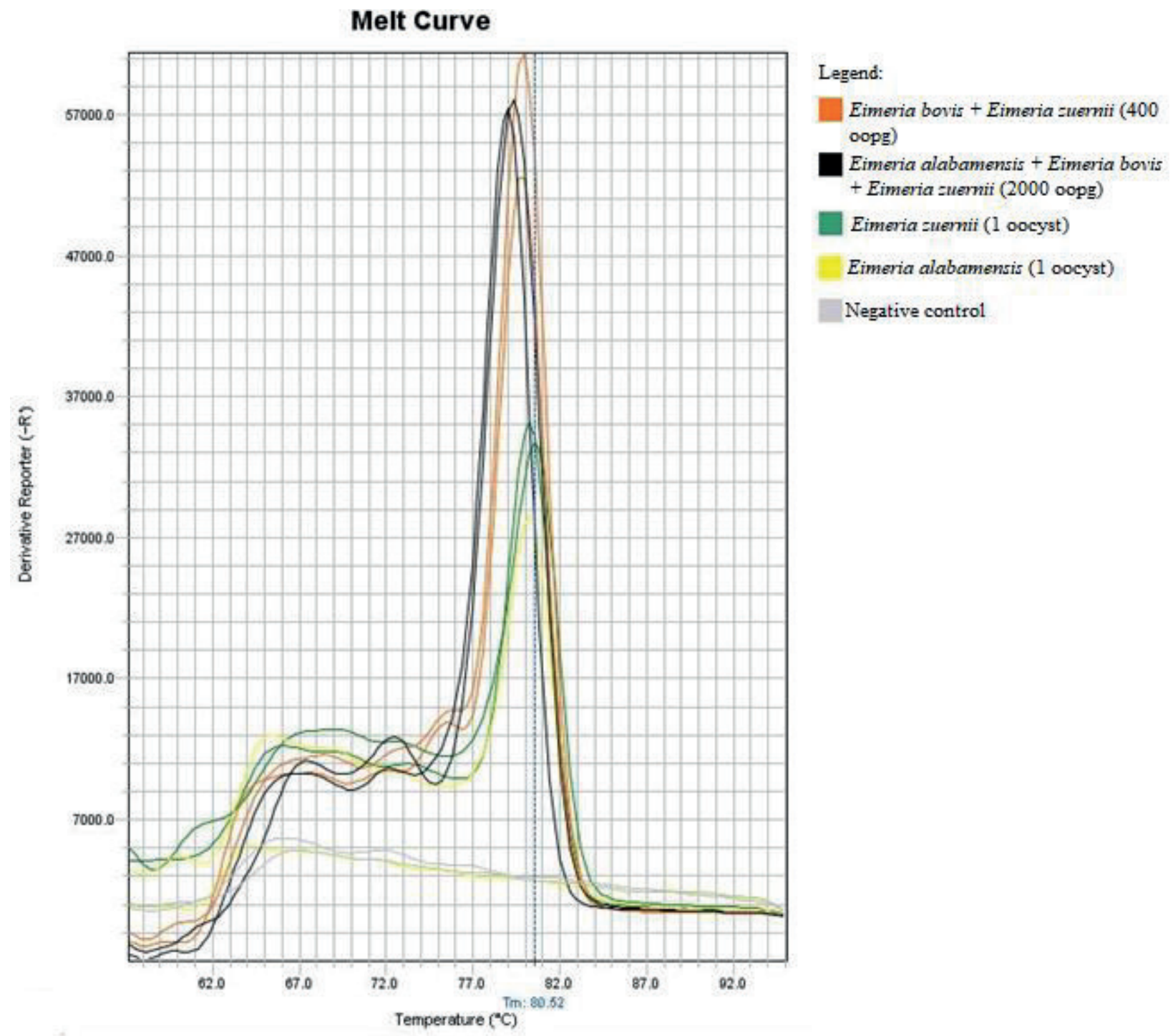

Figure 2. qPCR melting curve for Eimeria spp. based on the $18 \mathrm{~S}$ rRNA region.

\section{Conclusion}

The qPCR developed in this study could be used as a more sensitive alternative for routine diagnosis of Eimeria spp. in cattle fecal samples. In addition to being more sensitive than routine morphometry, this technique is less laborious and produces faster results. The development of a probe for TaqMan qPCR will be performed in the future.

\section{Acknowledgments}

This study recived financial support from the Coordenação de Aperfeiçoamento de Pessoal de Nível Superior (CAPES, INCT-Leite CAPES 016/2014). J.L. Garcia is recipient of CNPq fellowships. 


\section{References}

Abebe, R., Wossene, A., \& Kumsa, B. (2008). Epidemiology of Eimeria infections in calves in Addis Ababa and Debre Zeit dairy farms, Ethiopia. Journal of Applied Research in Veterinary Medicine, 6(1), 24-30.

Almeida, V. A., Magalhães, V. C. S., Muniz, E. S., Neta, \& Munhoz, A. D. (2011). Frequency of species of the genus Eimeria in naturally infected cattle in Southern Bahia, Northeast Brazil. Revista Brasileira de Parasitologia Veterinária, 20(1), 78-81. doi: 10.1590/S1984-29612011000100017

Bangoura, B., Mundt, H. C., Schmäschke, R., Westphal, B., \& Daugschies, A. (2011). Prevalence of Eimeria bovis and Eimeria zuernii in German cattle herds and factors influencing oocyst excretion. Parasitology Research, 109(2), 129-138. doi: 10.1007/s00436011-2569-z

Bruhn, F. R. P., Lopes, M. A., Demeu, F. A., Perazza, C. A., Pedrosa, M. F., \& Guimarães, A. M. (2011). Frequency of species of Eimeria in females of the Holstein Friesian breed at the post-weaning stage during autumn and winter. Revista Brasileira de Parasitologia Veterinária, 20(4), 303-307. doi: 10. 1590/S1984-29612011000400008

Bruhn, F. R. P., Silva, F. A., Jr., Carvalho, A. H. O., Orlando, D. R., Rocha, C. M. B. M., \& Guimarães, A. M. (2012). Ocorrences of Eimeria spp. and gastrointestinal nematodes in dairy calves in southern Minas Gerais, Brazil. Revista Brasileira de Parasitologia Veterinária, 21(2), 171-175. doi: 10.1590/S1984-296 12012000200019

Daugschies, A., Imarom, S., Ganter, M., \& Bollwahn, W. (2004). Prevalence of Eimeria spp. in sows at piglet producing farms in Germany. Journal of Veterinary Medicine, 51(3), 135-139. doi: 10.1111/j. 14390450.2004.00734.x

Florião, M. M., Lopes, B. B., Berto, B. P., \& Lopes, C. W. G. (2016). New approaches for morphological diagnosis of bovine Eimeria species: a study on a subtropical organic dairy farm in Brazil. Tropical Animal Health and Production, 48(3), 577-584. doi: 10.1007/s11250-016-0998-5

Hillesheim, L. O., \& Freitas, F. L. C. (2016). Ocorrência de eimeriose em bezerros criados em propriedades de agricultura familiar - nota científica. Ciência Animal Brasileira, 17(3), 472-481. doi: 10.1590/1089$6891 v 17 \mathrm{i} 333327$

Jonsson, N. N., Piper, E. K., Gray, C. P., Deniz, A., \& Constantinoiu, C. C. (2011). Efficacy of toltrazuril
5\% suspension against Eimeria bovis and Eimeria zuernii in calves and observations on the associated immunopathology. Parasitology Research, 109(1), 113-128. doi: 10.1007/s00436-011-2408-2

Kawahara, F., Zhang, G., Mingala, C. N., Tamura, Y., Koiwa, M., Onuma, M., \& Nunoya, T. (2010). Genetic analysis and development of species-specific PCR assays based on ITS1 region of rRNA in bovine Eimeria parasites. Veterinary Parasitology, 174(12), 49-57. doi: 10.1016/j.vetpar.2010.08.001

Khademvatan, S., Neisi, N., Maraghi, S., \& Saki, J. (2011). Diagnosis and identification of Leishmania spp. from Giemsa-stained slides, by real-time PCR and melting curve analysis in south-west of Iran. Annals of Tropics Medicine \& Parasitology, 105(8), 559-565. doi: 10.1179/2047773211Y.0000000014

Kokozawa, T., Ichikawa-Seki, M., \& Itagaki, T. (2013). Determination of phylogenetic relationships among Eimeria species, which parasitize cattle, on the basis of nuclear 18S rDNA sequence. The Journal of Veterinary Medicine Science, 75(11), 1427-1431. doi: 10.1292/jvms.13-0273

Koutny, H., Joachim, A., Tichy, A., \& Baumgartner, W. (2012). Bovine Eimeria species in Austria. Parasitology Research, 110(5), 1893-1901. doi: 10.1007/s00436-011-2715-7

Lentze, T., Hofer, D., Gottstein, B., Gaillard, C., \& Busato, A. (1999). Prevalence and importance of endoparasites in calves raised in Swiss cow-calf farms (Article in German.) Deutsche Tierärztliche Wochenschrift, 106(7), 275-281.

Marshall, R. N., Catchpole, J., Green, J. A., \& Webster, K. A. (1998). Bovine coccidiosis in calves following turnout. Veterinary Record, 143(13), 366-367. doi: 10.1136/vr.143.13.366

Matjila, P. T., \& Penzhorn, B. L. (2002). Occurrence and diversity of bovine coccidia at three localities in South Africa. Veterinary Parasitology, 104(2), 93102. doi: 10.1016/s0304-4017(01)00605-7

Nicolas, L., Milon, G., \& Prina, E. (2002). Rapid differentiation of Old World Leishmania species by LightCycle polymerase chain reaction and melting curve analysis. Journal of Microbiological Methods, 51(3), 295-299. doi: 10.1016/s0167-7012(02)000994

Ogedengbe, J. D., Hanner, R. H., \& Barta, J. R. (2011). DNA barcoding identifies Eimeria species and contributes to the phylogenetics of coccidian parasites (Eimeriorina, Apicomplexa, Alveolata). International Journal for Parasitology, 41(8), 843850. doi: 10.1016/j.ijpara.2011.03.007 
Rebouças, M. M., Grasso, L. M. P. S., Spósito, E. Fa, Amaral, V., Santos, S. M., \& Silva, D. M. (1994). Prevalência e distribuição de protozoários do gênero Eimeria (apicomplexa: Eimeriidae) em bovinos nos municípios de Altinópolis, Taquaritinga, São Carlos, Guaíra - Estado de São Paulo, Brasil. Revista Brasileira de Parasitologia Veterinária, 3(2), 125130.

Rehman, T. U., Khan, M. N., Sajid, M. S., Abbas, R. Z., Arshad, M., Iqbal, Z., \& Iqbal, A. (2011). Epidemiology of Eimeria and associated risk factors in cattle of district Toba Tek Singh, Pakistan. Parasitology Research, 108(5), 1171-1177. doi: 10.1007/s00436-010-2159-5

Sambrook, J., Fritshc, E. F., \& Maniatis, T. (1989). Molecular cloning: a laboratory manual (2a ed.). New York: Cold Spring Harbor Laboratory Press.
Stewart, I. D., Smith, R. P., \& Ellis-Iversen, J. (2008). Eimeria species in cattle on farms in England and Wales. Veterinary Record, 162(15), 482-483. doi: $10.1136 /$ vr.162.15.482

Svensson, C. (2000). Excretion of Eimeria alabamensis oocysts in grazing calves and young stock. Journal of Veterinary Medicine, 47(2), 105-110. doi: 10.1046/j.1439-0450.2000.00324.x

Svensson, C., Hooshmand-Rad, P., Pehrson, B., Törnquist, M., \& Uggla, A. (1993). Excretion of Eimeria oocysts in calves during their first three weeks after turn-out to pasture. Acta Veterinaria Scandinavica, 34(2), 175-182.

Svensson, C., Uggla, A., \& Pehrson, B. (1994). Eimeria alabamensis infection as a cause of diarrhoea in calves at pasture. Veterinary Parasitology, 53(1-2), 33-43. doi: 10.1016/0304-4017(94)90014-0 
